\title{
Pengembangan Model Pembelajaran Konseling Kelompok dengan Pendekatan Konstruktivistik
}

\author{
Indri Astuti*
}

\begin{abstract}
This research is aimed to observe the development to instructional model of group counceling using a constructivist approach. The methodology of the research is employing Borg and Gall combined with the instructional design by Dick and Carey. The steps of the research include (1) preliminary research; (2) planning model development; (3) validation, evaluation and revision of model. The concept of instructional constructivistic group counseling is intergrated between Gladding's group counseling namely (1) beginning, (2) transition, (3) activity, (4) and termintion. Cognan's (1) grouping, (2) situations, (3) intergrating, (4) questioning, (5) exhibition and reflection. This output of the research include instructional materials and student work sheet, group counseling guide and video of constructivistic group counseling.
\end{abstract}

Keywords: research and development, model learning, counseling group, counstructivistic

\begin{abstract}
Abstrak: Penelitian ini bertujuan untuk mengetahui pengembangan model pembelajaran konseling kelompok dengan pendekatan konstruktivistik. Metode penelitian yang digunakan adalah metode penelitian Borg dan Gall yang dikombinasikan dengan tahapan desain instruksional dari Dick dan Carey. Langkah-langkah penelitian dan pengembangan adalah (1) Penelitian Pendahuluan; (2) Perencanaan Pengembangan Model; (3) Validasi, Evaluasi, dan Revisi Model. Konsep pembelajaran konseling kelompok konstruktivistik integrasi antara tahapan konselling kelompok menurut Gladding yaitu: (1) pembentukan, (2) peralihan, (3) kegiatan, (4) pengakhiran, dan komponen pembelajaran konstruktivistik dari komponen konstruktivistik menurut Cognan yaitu: (1) pengelompokan, (2) situasi, (3) pengkaitan, (4) pertanyaan, (5) eksibisi dan (6) refleksi. Hasil penelitian dan pengembangan model berupa produk (1) Bahan Ajar dan Lembar Kerja peserta didik, (2) Panduan Pelaksanaan Konseling Kelompok dan Vidio Konseling Kelompok Konstruktivistik. Hasil validasi para ahli dan uji coba menunjukkan bahwa model tersebut layak digunakan dalam proses pembelajaran Konseling Kelompok untuk meningkatkan hasil belajar.
\end{abstract}

Kata kunci: penelitian dan pengembangan, model pembelajaran, konseling kelompok, konstruktivistik

\section{PENDAHULUAN}

Undang-Undang Nomor 20 Tahun 2003 pasal 1 butir 6 . Menyebutkan pendidik adalah tenaga kependidikan yang berkualifikasi sebagai guru, dosen, konselor, pamong belajar, widyaiswara, tutor, instruktur, fasilitator, dan sebutan lain sesuai dengan kekhususannya, serta berpartisipasi dalam penyelenggaraan pendidikan.

Pendidik merupakan tenaga profesional yang merencanakan proses pembelajaran, menilai hasil pembelajaran, melakukan pembimbingan, serta melakukan penelitian dan pengabdian kepada masyarakat terutama bagi pendidik di Perguruan Tinggi. Menyimak undang-undang tersebut konselor adalah pendidik. Tugas konselor/guru pembimbing sebagai pendidik adalah merencanakan proses pembelajaran, menilai hasil proses pembelajaran seperti guru, dosen dan pendidik lainnya. (Prayitno,

* Indri Astuti, Trainer Bidang PAUD Dinas Pendidikan Provinsi Kalimantan Barat 
pembimbing/ pendidik melaksanakan layanan konseling kelompok sebagai profesi yang bermartabat dan bermandat. Bermartabat membelajarkan peserta didik mengentaskan permasalahannya dan bertanggung jawab secara pribadi atas keputusan yang diambilnya. Bermandat profesi konseling mendapatkan pengakuan dari instansi terkait. Didukung pendapat Ki Hajar Dewantara (1977:25), bahwa dengan budi pekerti manusia mampu berdiri sendiri sebagai insan merdeka akan membentuk manusia yang beradab.

Pembelajaran harus memberikan tempat proses pemberdayaan diri, mulai dari pengembangan potensi diri secara optimal, sehingga peserta didik memiliki kekuatan spiritual keagamaan, pengendalian diri, kepribadian, kecerdasan, akhlak mulia dan keterampilan yang diperlukan oleh dirinya, masyarakat, bangsa dan negara. (ABKIN, 2013:5-6) Mengindikasikan konselor/pendidik dalam tugasnya meIaksanakan layanan konseling kelompok dengan kegiatan membelajarkan peserta didik atau sasaran layanan dalam suasana belajar dalam bentuk layanan konseling.

Kualitas pendidikan merupakan aspek penting yang harus selalu diperhatikan dalam penyelenggraan pendidikan. Melalui Peraturan Pemerintah No 19 tahun 2005 yang diperbarui dengan PP No 32 tahun 2013 tentang Standar Nasional Pendidikan. Penyelenggaraan pendidikan dalam implementasinya menggunakan kurikulum sebagai acuan proses pembelajaran di sekolah.

Perkembangan kurikulum pendidikan di Indonesia mengalami perubahan sejak kurikulum 2006 secara bertahap berganti kurikulum 2013. Implementasinya untuk layanan konseling kelompok berganti konsentrasi dari layanan bimbingan dan konseling menjadi layanan responsif. Begitu juga terjadi pada kurikulum di perguruan tinggi, berdasarkan pasal 97 tahun 2012 menyatakan bahwa kurikulum perguruan tinggi dikembangkan dan dilaksanakan berbasis kompetensi (KBK) berubah sesuai dengan Perpres RI 8 tahun 2012. Kurikulum perguruan tinggi mengacu pada kerangka kualifikasi nasional Indonesia (KKNI) tahun 2014.

Sesuai dengan KKNI, maka capaian pembelajaran mata kuliah konseling kelompok adalah mengembangkan kemampuan spiritual, emosional dan intelektual. Pembelajaran berpusat pada peserta didik dan evaluasi sesuai dengan kemampuan yang akan dicapai yaitu spiritual, emosional dan intelektual. Untuk itu seharusnya dosen menyusun rancangan pembelajaran yang sistemik dan sistematis, sehingga perumusan tujuan pembelajaran, penggunaan metode dan pemilihan evaluasi berkesinambungan sesuai KKNI.

Fakta di lapangan rancangan pembelajaran yang disusun dosen belum sistemik dan sistematis. Pembelajaran menjadi belum efektif. Tujuan pembelajaran hanya terfokus pada kemampuan intelektual, dan metode pembelajaran berpusat pada dosen, evaluasi mengungkap kemampuan intektual saja.

Hasil belajar mata kuliah konseling kelompok lebih dari separo (120 orang dari 182 orang) mendapatkan nilai rata-rata $(67,44 /$ kategori C). Mata kuliah konseling kelompok merupakan prasarat semester lima mata kuliah micro konseling/PPL, semester enam PPL di sekolah, seminar proposal dan skripsi.

Untuk itu, desain pembelajaran konseling kelompok perlu diperbaiki dengan pendekatan konstruktivistik untuk meningkatkan hasil belajar peserta didik Program Studi Bimbingan dan Konseling STKIP-PGRI Pontianak.

Menurut Gagnon dan Collay (2001:7), desain sistem pembelajaran konstruktivistik ada enam komponen penting dalam pembelajaran konstruktivistik yaitu: (1) situations), (2) (gruopings), (3) bridges, (4) questions, (5) exhibits , (6) reflections. Komponen ini menggambarkan secara komprehensif tentang maksud dan tujuan dilaksanakannya aktivitas pembelajaran. Berikut ini diskripsi komponen pembelajaran konstruktivistik: (1) Situasi juga tergambar tugas-tugas yang perlu diselesaikan oleh peserta didik agar mereka memiliki makna dari pengalaman belajar yang telah dilalui, (2) Pengelompokkan (gruopings). Komponen pengelompokan dalam aktivitas pembelajaran memberi kesempatan kepada peserta didik untuk melakukan interaksi dengan teman sejawat. Pengelompokkan sangat bergantung pada situasi atau pengalaman belajar yang ingin dilalui oleh peserta didik. Pengelompokkan dapat dilakukan secara acak atau random atau didasarkan pada kriteria tertentu (porposive). (3) Pengkaitan (bridges). Komponen pengkaitan dilakukan untuk menghubungkan pengetahuan yang telah dimiliki oleh peserta didik dengan pengetahuan yang baru. 
Bentuk-bentuk kegiatan pengkaitan sangat bervariasi, misalnya melalui pemecahan masalah atau melalui diskusi topik-topik yang spesifik. (4) Pertanyaan (questions) Pengajuan pertanyaan merupakan hal penting dalam aktivitas pem- belajaran. Pertanyaan akan memunculkan gagasan asli yang merupakan inti dari pendekatan pembelajaran konstruktivistik. Munculnya gagasan- gagasan yang bersifat orisinal peserta didik dapat membangun pengetahuan dalam dirinya. (5) Eksibisi (exhibits). Komponen eksibisi dalam pembelajaran yang menggunakan pendekatan konstruktivistik memberi kesempatan pada peserta didik untuk dapat menunjukkan hasil belajar setelah mengikuti suatu pengalaman belajar. (6) Refleksi (reflektions). Komponen ini pada dasarnya memberikan kesempatan kepada pendidik dan peserta didik untuk berpikir kritis tentang pengalaman belajar yang telah mereka tempuh baik personal maupun kolektif. Refleksi juga memberi kesempatan kepada peserta didik untuk berpikir tentang aplikasi dari pengetahuan yang telah mereka miliki.

Menurut Woolfolk (2007:347), pendekatan konstruktivistik yaitu, "pembelajaran yang menekankan pada peran aktifsiswa dalam membangun pemahaman dan memberi makna terhadap informasi atau peristiwa yang dialami." Artinya, dalam mempelajari ilmu pengetahuan peserta didik tidak hanya bersifat pasif, tetapi senantiasa mencari dan menggali pengetahuan baru. Esensi pandangan konstruktivisme dalam proses pembelajaran, yaitu: (1) Belajar sebagai proses membangun gagasan dari pada sekedar proses memperoleh pengetahuan, (2) Pembelajaran merupakan proses pembangunan pengetahuan berdasarkan interpretasi peserta didik secara personal, (3) belajar merupakan proses aktif peserta didik dari pada hanya sekedar mengkomunikasikan pengetahuan, (4) pembelajaran berlangsung secara kolaboratif.

Berdasarkan beberapa pendapat di atas, maka disarikan proses belajar yang berlandaskan teori belajar konstruktivisme dilakukan dengan memfasilitasi peserta didik memperoleh pengalaman belajar tentang pengetahuan yang sedang dipelajari. Sehingga pembelajaran berlangsung secara efektif, efisien dan menyenangkan. Pengembangan gagasan peserta didik akan terfasilitasi dan mengkomunikasikan gagasannya sebagai produk pengetahuannya sendiri, sehingga pembelajaran berpusat pada peserta didik. Sedangkan pembelajaran yang didominasi pendidik, yaitu dengan memberikan informasi yang harus dihafal, bertentangan dengan pandangan belajar konstruktivisme. Untuk itu, pembelajaran konseling kelompok perlu didesain agar peserta didik dapat memperoleh hasil belajar yang baik.

Komponan konseling kelompok, menurut Corey dikelompokkan menjadi enam tahap yaitu: (1) tahap pembentukan (2) tahap orientasi; (3) tahap transisi; (4) tahap kerja; (5) tahap konsolidasi dan (6) tindak lanjut. Sementara Yacobs dan Masson (2012:13) mengelompokkan tahap proses konseling kelompok menjadi tiga tahap, yakni: (1) tahap permulaan; (2) tahap kerja, (3) tahap penutupan. Gladding (2004: 12), 1) tahap awal (beginning); (2) tahap transisi (transition); (3) tahap kegiatan (working) dan (4) tahap pengakhiran (termination) .

Mencermati tahapan-tahapan konseling kelompok yang dikemukakan oleh para ahli, mempunyai kesamaan tahapan inti yaitu empat tahap di antaranya(1) tahap pembentukan atau tahap awal, (2) tahap peralihan atau tahap transisi, (3) tahap kegiatan atau tahap inti dan (4) tahap pengakhiran atau tahap penutup. Keempat tahapan ini merupakan satu kesatuan yang sistemik dan sistematis. Keberhasilan tahap pembentukan akan menentukan keberhasilan tahapan berikutnya.

Untuk itu tujuan penelitian ini adalah untuk merancang model pembelajaran konseling kelompok dengan pendekatan konstruktivistik dan efektifitas model pembelajaran konseling kelompok kontruktivistik pada Program Studi Bimbigan dan Konseling STKIP-PGRI Pontianak.

\section{METODE PENELITIAN}

Penelitian ini dilaksanakan di Sekolah Tinggi Keguruan Ilmu Pendididkan (STKIP- PGRI) Pontianak. Waktu penelitian dilaksanakan pada bulan Juli 2013 - Desember 2013. Pada studi pendahuluan peneliti menggunakan respon peserta didik yang telah mengikuti mata kuliah konseling kelompok dan daftar penilaian nilai akhir (DPNA) hasil belajar peserta didik yang telah mengikuti mata kuliah konseling kelompok.

Metode penelitian yang digunakan adalah penelitian dan pengembangan (Research and Development) dari Borg and Gall untuk tahapan penelitiannya dan pengembangannya mengikuti tahapan Dick dan Carey. Dalam bidang pendidikan, 
$R$ and $D$ diarahkan pada pengembangan produk yang efektif bagi keperluan pembelajaran dan merupakan penelitian terapan. Untuk perbaikan (what works better) daripada kemengapaan (why), dan mementingkan kegunaannya dalam pendidikan (Gall, dkk, 2007: 186 - 187).

Model Dick dan Carey memiliki tahapantahapan sebagai berikut (1) mengidentifikasi tujuan pembelajaran; (2) melaksanakan analisis pem- belajaran; (3) mengidentifikasi tingkah laku dan karakteristik siswa; (4) merumuskan tujuan performansi; (5) mengembangkan butir tes dan acuan patokan; (6) mengembangkan strategi pembelajaran; (7) mengembangkan materi pembelajaran; (8) mendesain dan melaksanakan evaluasi formatif; (9) merevisi bahan pembelajaran, (10) mendesain dan melaksanakan evaluasi sumatif. Penelitian ini sampai pada 8 yaitu evaluasi Formatif. Berikut ini langkah-langkah penelitian: (1) Tahap Pra Pengembangan: langkah satu: penelitian pendahuluan dengan analisis kebutuhan dan studi literatur. Langkah dua; melakukan perencanaan model pembelajaran. Langkah ketiga: Pengembangan draf model, pengembangan draf bahan ajar dan pengembangan draf evaluasi. (2) Tahap Pengembangan Model: Validasi ahi desain pembelajaran, ahli materi, ahli media dan dosen pengampu mata kuliah. Lanjut revisi draf model berdasarkan masukan para ahli. (3) Tahap Uji Coba Evaluasi dan Revisi. Meliputi langkah 4: Uji coba lapangan awal. Langkah 5: Revisi ptoduk hasil uji coba awal. Langkah lima: Revisi produk hasil uji coba awal. Langkah enam: Uji coba lanjutan dan evaluasi.

Prosedur pengumpulan data yang di- gunakan dalam penelitian pendahuluan adalah : 1) observasi, 2) angket, 3) wawancara, dan 4) studi dokumentasi. Pada tahap uji coba peneliti menggunakan angket, wawancara, dan observasi. Analisis data yang digunakan adalah adalah kualitatif dan kuantitatif. Analisis data kualitatif dilakukan melalui penafsiran secara langsung untuk menyusun kesimpulan. Data kuantitatif dilakukan dalam proses uji coba untuk melihat persentase respon subjek uji coba. Pada uji coba lapangan dilakukan analisis data kuantitatif untuk melihat efektivitas penggunaan model terhadap penguasaan materi pembelajaran konstruktivistik dengan mencari selisih antara hasil pre test dan post test. Proses analisis secara statistik dilakukan dengan uji-t untuk mengetahui efektivitas model pembelajaran konseling kelompok konstruktivistik terhadap hasil belajar sesudah dilakukannya proses pembelajaran.

Tahapan pengembangan model terdapat (1) model konseptual, (2) model prosedural, dan (3) model fisikal. Model konseptual adalah model yang bersifat analitis, yang menyebutkan komponenkomponen produk, menganalisis komponen secara rinci dan menunjukkan hubungan antar komponen yang akan dikembangkan. Model prosedural adalah model yang bersifat deskriptif, menunjukkan langkah yang harus diikuti untuk menghasilkan produk. (Pusat Penelitian Kebijakan dan Inovasi Pendidikan Badan Penelitian dan Pengembangan, 2008: 8-9). Model fisikal adalah model dalam bentuk fisik.

\section{HASIL PENELITIAN DAN PEMBAHASAN}

Hasil penelitian meliputi hasil dari (1) Pengembangan model, (2) Kelayakan model, dan (3) Efektivitas model.

\begin{tabular}{|c|c|c|}
\hline No & Indikator & Hasil Penelitian \\
\hline 1 & $\begin{array}{l}\text { Pengertian } \\
\text { Capaian } \\
\text { Pembelajaran }\end{array}$ & $\begin{array}{l}\text { Pemahaman masih kurang } \\
\text { tentang pembelajaran } \\
\text { dengan pendekatan } \\
\text { konstruktivistik, tujuan } \\
\text { pembelajaran dan tagihan } \\
\text { mata kuliah kurang } \\
\text { dipahami. }(29,35 \%)\end{array}$ \\
\hline 2 & $\begin{array}{l}\text { Penyajian } \\
\text { Materi } \\
\text { Pembelajaran } \\
\text { Konseling } \\
\text { Kelompok }\end{array}$ & $\begin{array}{l}\text { Materi pembelajaran } \\
\text { konstruktivistik kurang } \\
\text { dipahami oleh responden } \\
\text { diantaranya dinamika } \\
\text { kelompok, struktur } \\
\text { kelompok, tahapan } \\
\text { konseling kelompok dan } \\
\text { pendektaan kelompok. } \\
\text { penyajian materi kurang } \\
\text { sistematis. }(25.5 \%)\end{array}$ \\
\hline 3 & $\begin{array}{l}\text { Metode } \\
\text { Pembelajaran }\end{array}$ & $\begin{array}{l}\text { Pembelajaran } \\
\text { berpusat pada masih } \\
\text { Ceramah } \\
\text { mendominasi }(10,5 \%) \\
\text { masih }\end{array}$ \\
\hline 4 & $\begin{array}{l}\text { Ketersediaan } \\
\text { Perangkat } \\
\text { Pembelajaran }\end{array}$ & $\begin{array}{l}\text { Responden memerlukan } \\
\text { bahan- Bahan pembelajaran } \\
\text { berupa bahan ajar, panduan } \\
\text { konseling kelompok dan } \\
\text { lembar kerja untuk praktik } \\
\text { konseling } \\
(20,15)\end{array}$ \\
\hline 5 & $\begin{array}{l}\text { Evaluasi } \\
\text { Pembelajaran }\end{array}$ & $\begin{array}{l}\text { Evaluasi kognitif belum ada } \\
\text { refleksi diakhir } \\
\text { pembelajaran }(15,40)\end{array}$ \\
\hline
\end{tabular}

Tabel 1. Hasil Pendapat Responden dalam Penelitian Pendahuluan 


\section{Pengembangan Model}

Pada pengembangan model, hasil penelitian dibagi: (a) hasil penelitian pendahuluan; (b) model awal; (c) model konseptual; dan (d) model final.

Berdasarkan tabel 1 dapat disimpulkan bahwa dosen sudah mengenal pembelajaran konstruktivistik. Namun, dosen masih perlu diberi pemahaman tentang perancangan pembelajaran konstruktivistik yang sistemik dan sistematis.

Berdasarkan tabel 1 dapat disimpulkan bahwa dosen sudah mengenal pembelajaran konstruktivistik. Namun, dosen masih perlu diberi pemahaman tentang perancangan pembelajaran konstruktivistik yang sistemik dan sistematis.

Pedalaman hasil kuesioner dilengkapi dengan wawancara dengan peserta didik. Berikut adalah rangkuman hasil wawancara.

Tabel 2. Hasil Wawancara dengan Peserta Didik

\begin{tabular}{|c|l|l|}
\hline No & \multicolumn{1}{|c|}{ Indikator } & \multicolumn{1}{|c|}{ Hasil Penelitian } \\
\hline 1 & $\begin{array}{l}\text { Capaian } \\
\text { Pembelajaran }\end{array}$ & $\begin{array}{l}\text { Deskripsi masih umum, } \\
\text { belum menyampaikan } \\
\text { tagihan mata kuliah dan } \\
\text { capaian pembelajaran untuk } \\
\text { lulusan mata kuliah konseling } \\
\text { kelompok. }\end{array}$ \\
\hline 2 & $\begin{array}{l}\text { Penyajian materi } \\
\text { Pembelajaran }\end{array}$ & $\begin{array}{l}\text { Perancangan pembelajaran } \\
\text { disusun tidak dilakukan } \\
\text { refleksi, revisi dan evaluasi. }\end{array}$ \\
\hline 3 & $\begin{array}{l}\text { Metode } \\
\text { pembelajaran }\end{array}$ & $\begin{array}{l}\text { Peserta didik belum } \\
\text { dioptimalkan } \\
\text { mengembangkan gagasan, } \\
\text { masih berpusat pada } \\
\text { aktivitas dosen. }\end{array}$ \\
\hline 4 & $\begin{array}{l}\text { Ketersediaan } \\
\text { Perangkat } \\
\text { Pembelajaran }\end{array}$ & $\begin{array}{l}\text { Perangkat bahan-bahan } \\
\text { pembelajaran belum tersedia } \\
\text { berupa panduan pelaksanaan } \\
\text { konseling kelompok, bahan } \\
\text { ajar dilengkapi lembar } \\
\text { kegiatan peserta didik. }\end{array}$ \\
\hline 5 & $\begin{array}{l}\text { Evaluasi } \\
\text { Pembelajaran } \\
\text { Mengukur kompetensi } \\
\text { untelektual, bentuk tes } \\
\text { uraian. }\end{array}$ \\
\hline
\end{tabular}

Berdasarkan Tabel 2 dapat disimpulkan bahwa pembelajaran berpusat pada dosen. Aktivitas peserta didik dalam pembelajaran konseling kelompok masih kurang. Dosen belum menyusun rancangan pembelajaran semester dengan sistemik dan sistematis. Pelaksanaan pembelajaran belum menggunakan pendekatan konstruktivstik. Penilaian aspek kognitif belum mengukur praktik konseling kelompok. Untuk itu diperlukan seperangkat pembelajaran yang dapat mempermudah peserta didik dalam belajar.

Hasil wawancara dengan dosen dirangkum seperti terdapat pada tabel 3 .

Tabel 3. Hasil Wawancara dengan Dosen

\begin{tabular}{|c|l|l|}
\hline No & \multicolumn{1}{|c|}{ Indikator } & \multicolumn{1}{c|}{ Hasil Penelitian } \\
\hline 1 & $\begin{array}{l}\text { Capaian } \\
\text { Pembelajaran }\end{array}$ & $\begin{array}{l}\text { Dosen sudah mengetahui } \\
\text { pembelajaran } \\
\text { konstruktivistik. Namun, } \\
\text { belum optimal dilakukan } \\
\text { dalam pembelajaran } \\
\text { konseling kelompok, }\end{array}$ \\
\hline 2 & $\begin{array}{l}\text { Penyajian Materi } \\
\text { Konseling } \\
\text { Kelompok }\end{array}$ & $\begin{array}{l}\text { Dosen sudah dapat membuat } \\
\text { RKP, tetapi belum membuat } \\
\text { rancangan yang }\end{array}$ \\
\hline 3 & $\begin{array}{l}\text { Metode } \\
\text { Pembelajaran }\end{array}$ & $\begin{array}{l}\text { Pembelajaran masih banyak } \\
\text { berpusat pada dosen. }\end{array}$ \\
\hline 4 & $\begin{array}{l}\text { Ketersediaan } \\
\text { Perangkat } \\
\text { Pembelajaran }\end{array}$ & $\begin{array}{l}\text { Belum tersedia dan } \\
\text { membutuhkan perangkat } \\
\text { pembelajaran yang dapat } \\
\text { mempermudah peserta didik } \\
\text { belajar. }\end{array}$ \\
\hline 5 & Evaluasi & $\begin{array}{l}\text { Penilaian ketuntasan belajar } \\
\text { belum dipahami. }\end{array}$ \\
\hline
\end{tabular}

Berdasarkan tabel 3 dapat disimpulkan bahwa dosen masih belum memahami secara maksimal tentang pembelajaran konstruktivistik. Dosen juga belum membuat rancangan pembelajaran secara sistemik dan sistematis. Oleh karena itu, masih memerlukan perangkat pembelajaran yang dapat mempermudah peserta didik belajar.

Hasil kusioner dan wawancara dilengkapi dengan observasi pembelajaran di kelas. Data pembelajaran di kelas terdiri atas (1) kegiatan pembukaan, (2) kegiatan inti, (3) kegiatan penutup. Hasil observasi pembelajaran dapat dirangkum pada tabel berikut. 
Tabel 4. Hasil Observasi Pembelajaran

\begin{tabular}{|l|l|}
\hline \multicolumn{1}{|c|}{ Aspek } & \multicolumn{1}{c|}{ Hasil Penelitian } \\
\hline Kegiatan & $\begin{array}{l}\text { Penyampaian diskripsi mata kuliah } \\
\text { secara umum. Capaian } \\
\text { pembelajaran tidak disampaiakn } \\
\text { dengan jelas, sehingga peserta } \\
\text { didik tidak tau arah mata kuliah. }\end{array}$ \\
\hline $\begin{array}{l}\text { Kegiatan } \\
\text { Inti }\end{array}$ & $\begin{array}{l}\text { Dosen masih banyak } \\
\text { mendominasi dalam } \\
\text { pembelajaran, sehingga } \\
\text { pembelajaran kurang berpusat } \\
\text { pada siswa.. }\end{array}$ \\
\hline Kegiatan & $\begin{array}{l}\text { Belum ada kegiatan merangkum } \\
\text { dan refleksi. Tidak ada penugasan } \\
\text { untuk peserta didik. Pembelajaran } \\
\text { diakhiri dengan doa. }\end{array}$ \\
\hline
\end{tabular}

Berdasarkan tabel 4 tersebut dapat disimpulkan bahwa pembelajaran masih tampak monoton. Pembelajaran kurang menyenangkan dan belum membuat peserta didik aktif membangun gagasan. Masih terdapat kesulitan dan hambatan ketika kegiatan pengungkapan masalah dan pembahasan masalah kegiatan. Pada kegiatan penutup dosen belum mengadakan kegiatan refleksi.

\section{b. Model awal}

Model awal yang secara konseptual dikembangkan berdasarkan model pembelajaran konstruktivistik Gagnon dan Collay (2001:7). Model awal terdiri dari komponen masukan meliputi tujuan pembelajaran, karakteristik peserta didik dan karaktristik mata kuliah konseling kelompok. Sedangkan komponen proses meliputi bahan ajar, enam indikator pembelajaran konstruktivistik masuk dalam unsur strategi pembelajaran dan evaluasi kompetensi kognitif dan keterampilan. Model awal konseptual yang dikembangkan di antaranya bahan ajar, panduan dan lembar kerja peserta didik untuk praktik konselingkelompok.. Model Konseptual

Model ini merupakan hasil revisi dari model awal yang telah mengalami validasi dari desain ahli teknologi pendidikan, ahli materi, dan ahli media. Ahli desain teknologi pendidikan memvalidasi kaitan antara Bahan ajar dan Buku panduan, serta Lembar kerja peserta didik praktik konseling kelompok konstruktivistik. Ahli materi memvalidasi dari kelayakan materi, penyajian materi, kebahasaan, dan grafika. Bentuk fisiknya berupa pembuatan rencana pembelajaran semester (RPS). Ahli media memvalidasi secara khusus tata tulis, desain grafis baik cover maupun isi bahan ajar, panduan dan lembar kerja praktik konseling kelompok dan contoh CD pembelajaran konseling kelompok.

\section{c. Model Draf Akhir}

Model draf akhir pembelajaran konseling kelompok konstruktivistik menampilan model secara utuh yang terdiri atas (1) model konseptual; (2) model prosedural, dan (3) model fisikal.

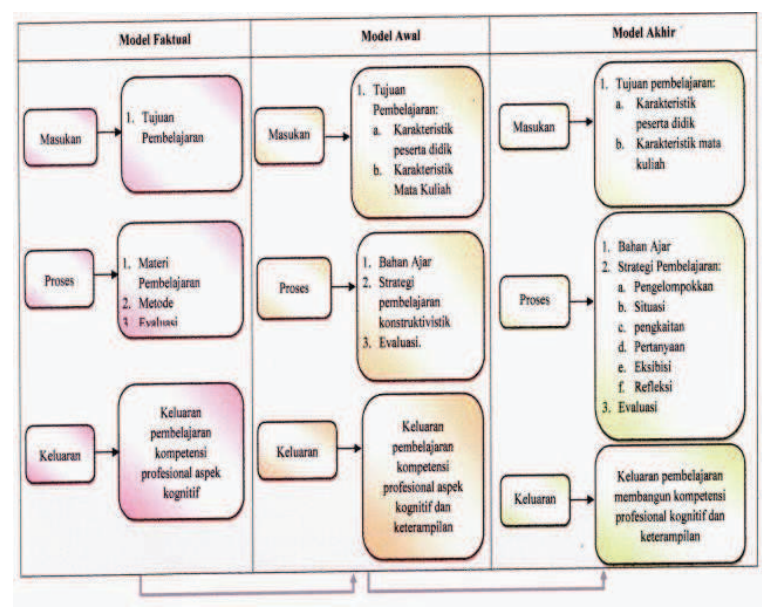

Gambar 1. Model Utuh Pembelajaran Konseling Kelompok Konstruktivistik

\section{Kelayakan Model}

Kelayakan model dirumuskan berdasarkan uji coba pakar, yang terdiri atas desain ahli teknologi pendidikan, ahli materi, dan ahli media. Hasil validasi para pakar adalah sebagai berikut.

Berdasarkan tabel 5 tersebut dapat dijelaskan bahwa masih diperlukan perbaikan pada rancangan model konseptual agar sesuai dengan konsep konstruktivistik. Hasil kelayakan dari ahli materi rata-rata adalah baik. Hal yang harus diperbaiki dari kegrafikan adalah hirarki penggunaan font huruf pada teks pada setiap gambar yang ada dalam bahan ajar. Masukan dari para ahli digunakan sebagai bahan untuk memperbaiki model, sehingga didapat model draf final yang akan diuji coba ke peserta didik. 
Tabel 5. Hasil Validasi Ahli

\begin{tabular}{|l|l|}
\hline \multicolumn{1}{|c|}{ Ahli } & \multicolumn{1}{c|}{ Hasil Validasi } \\
\hline $\begin{array}{l}\text { Ahli Desain } \\
\text { Teknologi } \\
\text { Pendidikan }\end{array}$ & $\begin{array}{l}\text { Relevansi rancangan model } \\
\text { konseptual dengan kebutuhan di } \\
\text { lapangan dinilai baik. Penerapan } \\
\text { konsep baik. Yang masih harus } \\
\text { diperbaiki adalah rancangan model } \\
\text { konseptual berdasarkan } \\
\text { konstruktivistik. Hasil validasi } \\
\text { memberikan skor rata-rata 4,1 }\end{array}$ \\
\hline Ahli Materi & $\begin{array}{l}\text { Hasil validasi ahli materi skor rata- } \\
\text { rata } \\
3,75 \text { (baik) sehingga produk }\end{array}$ \\
\hline Ahli Media & $\begin{array}{l}\text { Skor rata-rata di atas 3,81(baik) } \\
\text { namun masih ada hal-hal yang } \\
\text { harus diperbaiki terutama pada } \\
\text { konsistensi penggunaan font huruf } \\
\text { dan kejelasan ilustrasi gambar } \\
\text { dengan penggnaan warna serta teks. }\end{array}$ \\
\hline
\end{tabular}

\section{Efektivitas Model}

Gambaran efektivitas model akan terlihat dari kebergunaan dan kebermanfaatan model yang dikembangkan. Adapun kebergunaan dan kebermanfaatan model dapat dilihat dari (1) respon subjek uji coba dan (2) hasil belajar yang diperoleh subjek uji coba. Respon subjek uji coba dapat dilihat (a) Uji One to One; (2) Uji Kelompok Kecil, (3) Uji Kelompok lapangan.

\section{a. Uji One to One}

Hasil pendapat subjek uji coba one to one adalah menggunakan tiga orang peserta didik dari tiga kelas masing-masing satu orang dengan kemampuan yang berbeda. Hasilnya sebagai berikut: semua peserta didik tertarik pada produk karena keberadaan secara fisik bahan ajar, panduan dan lembar kerja praktik konseling kelompok terutama tampilan gambar dan warna yang menarik; dua orang peserta didik menyatakan ada gambar yang tidak jelas karena tidak ada teks, seorang peserta didik menyatakan ada kegiatan yang tidak bisa dilakukan karena tidak ada keterangan teks dan gambar.

Masukan dari uji one to one itu digunakan untuk bahan revisi produk. Produk yang sudah direvisi kemudian diuji coba pada uji coba kelompok kecil.

\section{b. Uji Kelompok Kecil}

Hasil uji kelompok kecil adalah dari 9 orang di ambli dari tiga kelas yang berbeda. Uji coba kelompok kecil dikenakan 9 peserta didik di ambil dari tiga kelas yang berbeda dan representatif untuk populasi sarana yang sebenarnya yaitu 3 orang kemampuannya di atas rata-rata dan 3 orang mempunyai kemampuan rata-rata serta 3 orang dibawah rata-rata. Masukan yang diperoleh pada bahan ajar sistematika $(91,67 \%)$, kompetensi $(87,50 \%)$, materi $(87,18 \%)$, evaluasi $(86,81 \%)$. Mengisyaratkan bahan ajar sesuai kebutuhan peserta didik untuk pembelajaran konseling kelompok. Namun masih ada perbaikan tentang gambar, konsistensi huruf dan peletakan teks serta pewarnaan. Sedangkan praktik konseling kelompok, tahap pembentukan (85\%), tahap peralihan $(88,89 \%)$, tahap kegiatan $(85 \%)$ dan tahap pengakhiran $(84,89 \%)$. Menunjukkan bahwa peserta didik telah memahami indikator di setiap tahapan konseling kelompok. Saran bagan alir praktik konseling kelompok dilengkapi panduan pelaksanaan konseling kelompok dengan unsur visi, misi, tujuan, dan prosedur pelaksanaan serta evaluasi.

Masukan dari uji coba kelompok kecil digunakan sebagai bahan revisi produk. Produk yang sudah direvisi akan diuji coba pada uji coba lapangan.

\section{c. Uji Coba Kelompok Lapangan.}

Uji coba kelompok besar dilakukan dengan observasi pembelajaran selama 7 kali pembelajaran. Kelas uji coba adalah kelas A pagi (23) dan B Pagi (26) dan A Siang (21) peserta didik. Indikator tanggapan subjek uji coba sama dengan uji kelompok kecil. Sedangkan uji coba kelompok besar dilakukan pre test dan pos test untuk melihat efektivitas model dari hasil belajar peserta didik. berikut ini rangkuman hasil pre dan pos hasil belajar konseling kelompok.

Tabel 6. Hasil Pretes dan Postes

\begin{tabular}{|c|c|c|c|}
\hline Kelas & Pre Tes & Post Tes & Selisih \\
\hline A Pagi & 66,41 & 81,52 & 15,11 \\
\hline B Pagi & 67,60 & 81,54 & 13,94 \\
\hline A siang & 68,10 & 81,55 & 13,45 \\
\hline
\end{tabular}


Berdasrkan tabel 6 dapat disimpulkan bahwa produk tersebut dapat meningkatkan hasil belajar peserta didik sehingga layak digunakan dalam proses pembelajaran.

Berikut ini ditampilkan dalam betuk grafik

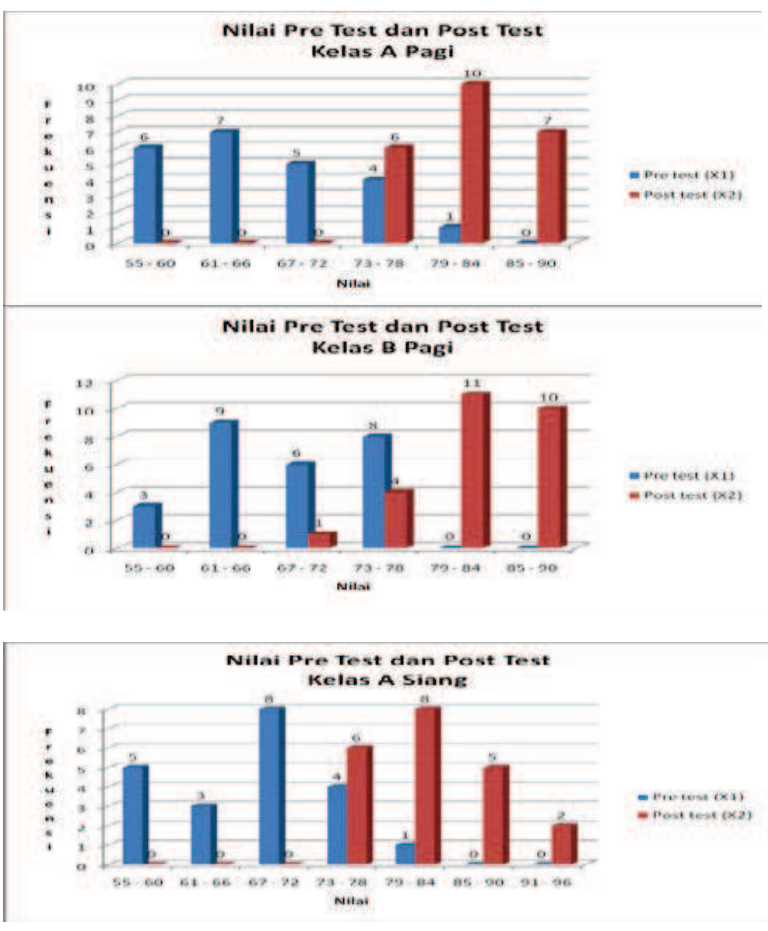

\section{PEMBAHASAN}

Pembelajaran konstruktivistik diterapkan pada KKNI dan kurikulum di Satuan pendidikan. Pelaksanaan pembelajaran masih terdapat banyak kendala, yaitu ketidakjelasan pada perancangan pembelajaran, proses pembelajaran, dan penilaian. Oleh karena itu, pembelajaran tidak efektif dan diperlukan sebuah model pembelajaran yang dapat membantu terlaksanakan pembelajaran dengan baik.

Model pembelajaran konstruktivistik yang dikembangkan pada penelitian ini adalah model yang mengacu pada (1) model konseptual, (2) model prosedural, dan (3) model fisikal.

Secara konseptual, model dikembangkan berdasarkan teori model pembelajaran konstruktivistik dari Gagnon dan Collay (2001:7), bahwa komponen pembelajaran ada enam yaitu (1) situations), (2) (gruopings), (3) bridges, (4) questions, (5) exhibits, (6) reflections. Sedangkan tahapan-tahapan konseling kelompok dari Gladding
(2004: 7), meliputi tahap awal (beginning); (2) tahap transisi (transition); (3) tahap kegiatan (working) dan (4) tahap pengakhiran (termination). Model yang menunjukkan pembelajaran terintegrasi dengan memperhatikan keterampilan, pengetahuan, dan sikap.

Secara prosedural, model pembelajaran pada penelitian ini dikembangkan berdasarkan model Dick dan Carey. Model tersebut merupakan salah satu model prosedural yang menyarankan penerapan desain pembelajaran agar disesuaikan dengan langkah-langkah yang harus ditempuh secara berurutan. Salah satu kelebihan dari model Dick dan Carey adalah adanya tahapan evaluasi formatif dan revisi pada setiap langkah. Model fisikal yang dihasilkan adalah produk berupa Buku bahan ajar, Panduan konseling kelompok, Buku latihan kerja peserta didik untuk praktik konseling kelompok. Setelah mengalami validasi dan uji coba lapangan, diperoleh hasil bahwa model secara efektif dapat meningkatkan hasil belajar peserta didik dalam pembelajaran konseling kelompok.

\section{KESIMPULAN}

Kesimpulan penelitian ini sebagai berikut. (1) Rancangan model pembelajaran konseling kelompok dengan pendekatan konstruktivistik dikembangkan berdasarkan model konseptual, model prosedural, dan model fisikal. (2) Efektivitas pembelajaran konseling kelompok konstruktivistik model fisikal terdiri atas bahan ajar, panduan konseling kelompok, latihan kerja peserta didik. Berikut ini hasil respon peserta didik terhadap bahan hajar menunjukkan kelas A Pagi memberikan respon baik terhadap bahan ajar dengan rata-rata $(86,89 \%)$. Artinya bahan ajar menarik mudah dipahami dengan bahasa sederhana dan sesuai kebutuhan peserta didik. Bahan ajar disusun sesuai dengan kompetensi mata kuliah. Selanjutnya Kelas B Pagi memberikan respon baik dengan rata-rata $(89,19$ $\%$ ), artinya bahan ajar menarik dan efektif untuk digunakan dalam mata kuliah konseling kelompok. Sistematika bahan ajar mempermudah peserta didik dalam menggunakannya, dengan rata- rata $(90,06)$. Sementara Kelas B Siang memberikan respon dengan rata-rata $(91,19)$, artinya bahan ajar sangat menarik dan efektif untuk digunakan, dengan tampilan gambar dan bagan yang sangat membantu peserta didik. Uraian materi sangat sesuai dengan kebutuhan peserta didik dan mudah dipahami, dengan 
rangkuman, dan latihan. Berdasarkan temuan dari ketiga kelas yang memberikan respon dengan ratarata-rata sangat baik, maka mengindikasikan bahan ajar efisien dan menarik dengan sistematika sesuai konsep dasar dan praktik konseing kelompok, materi yang memadai dan dilengkapi dengan evaluasi dan reflleksi.

Respon Dosen terhadap Pembelajaran Konseling Kelompok Konstruktivistik hasilnya untuk kejelasan rancangan model pembelajaran $(83,34 \%)$ menyatakan sangat jelas dan $(16,67 \%)$ menyatakan jelas. Untuk kejelasan setiap tahapan model menyatakan $(83,33 \%)$ sangat jelas dengan tahapan penggunaan model, sementara (16,66\%) menyatakan jelas dan masih ada yang belum dipahami yaitu tentang penggunaan bagan alirkonseling kelompok. Selanjutnya strategi penilaian pembelajaran yang akan dilaksanakan ada $(66,63 \%)$ menyatakan sangat sesuai dengan karakteristik konseling kelompok. selebihnya $(33,34 \%)$ masih ada bagian yang belum sesuai sehingga memerlukan penjelasan. Adapun bentuk penilaian yang memerlukan penjelasan adalah penilaian praktik konseling kelompok. Keyakinan untuk melaksanakan model menunjukan $(83,33 \%)$ menunjukkan yakin dapat melaksanakan dan selebihnya $(16,66 \%)$ berusaha untuk mencobanya. Kesulitan belum ditemukan karena belum melaksanakan. Komentarnya pembelajaran akan menarik dan menantang, peserta didik akan termotivasi untuk belajar mandiri.

\section{DAFTAR RUJUKAN}

Anita Wolfolk, Educatioan Pyscology. Pearson, Inc. 2007.

Atwi Suparman, Desain Instruksional Modern. Jakarta: Erlangga. 2012.

Borg, Wolter R. \& Meredith D. Gall. Educational Research An Introduction, 7th ed. Boston: Pearson Education Inc, 2003.

Corey Gerald, Marianne Schneider Corey, dan Gerald Corey, Group Prosess and Practice. Australia: Thomson Brooks/Cole, 2006.

Dewantara, Ki Hajar. Bagian I - Pendidikan. Yogjakarta: Majelis Luhur Persatuan TamanSiswa, 1977.

Elaine B. Johnson, Contextual Teaching andLearning. Bandung: Kaifa. 2009.
Gagnon Jr. George W. \& Collay Michelle, Designing for Learning Six in Costructivist Classrooms. California: Corein Press, Inc,2001.

Gladding, Samuel T. Counseling A Comprehensive Profession. Columbus, Ohio: Upper Saddle River. New Yersey, 2004.

Jacobs, ED E. et al. Group Counseling : Strategi and Skills. California: Brook/Cole Publishing Company, 2012.

Panduan Umum Pelayanan Bimbingan dan Konseling pada Satuan Pendidikan Dasar dan Menengah. Semarang: ABKIN, 2013.

Prayitno, Mengatasi Krisis Identitas ProfesiKonselor. Padang: FKIP,2013.

Pusat Penelitian Kebijakan dan Inovasi Pendidikan Badan Penelitian dan Pengembangan, Metode Penelitian Pengembangan, Jakarta: Departemen Pendidikan Nasional. 2009.

Walter Dick, Lou Carey, dan James O Carey, The Systemic Design of Instruction. Boston: Pearson. 2005.

Wolfoofolk, Anita. Educational Psychology. Boston: Person Educational Inc,2007. 